\title{
The Selection Decision: Defining Criteria and Establishing Priorities
}

\section{John Rutledge and Luke Swindler}

This article discusses the specific selection criteria used in making collection development decisions. The criteria are grouped into six major categories, and within each category they are arranged in order cf relative importance. The proposed schematization provides librarians who have collection development responsibilities with a holistic and explicit model for arriving at a selection decision as well as a mechanism for assigning a specific priority to each selection. Use of such a model can help to rationalize selection decisions; it relates acquisitions effectively and convincingly to a library's fiscal environment; and it promotes cooperative collection development.

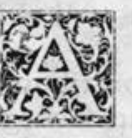

German proverb states, "Whoever has the choice, also has the misery." Making choices is no easy business, yet selecting materials is one of the principal functions of collection development officers. Even in libraries that rely heavily on approval plans, selectors must review titles individually to ensure an effective collection development program. Despite the centrality of selection decision making to the collection development process, there are few tools that offer practical assistance for the performance of this intellectual task, particularly in academic settings. Moreover, the guides found in the published literature are not truly comprehensive, and none provides a practical means of relating selection to a library's acquisitions budget. While a collection development officer may be called upon to select or reject hundreds of titles during the course of the working day and is generally proficient at making these choices, he or she could still benefit from a convenient tool that rationally organizes the factors contributing to an acquisitions decision. This would be particularly helpful if funds are insufficient for acquiring all appropriate titles or if the library is seriously attempting to implement cooperative collection development programs.

Selection officers typically receive little assistance from their own library when making decisions. Even the best and most widely known collection policies merely state what a library ideally would select in a world without financial constraints, while a few policies also indicate the existing level of collecting. ${ }^{1}$ A unique tool, the Bibliographer's Manual, prepared by the collection development staff of the University of Texas at Austin Library, serves as a guide to the collection development system and selection procedures rather than to the decision-making process itself. ${ }^{2} \mathrm{~A}$ more general guide used in many libraries is ALA's Guidelines for Collection

John Rutledge is West European Bibliographer and Luke Swindler is Social Sciences Bibliographer at the University of North Carolina, Chapel Hill, North Carolina 27514. 
Development. ${ }^{3}$ This otherwise useful handbook covers the formulation of a collection development policy and the evaluation of the results of selection, but does not deal with the specific selection decision making that is central to the collection development process.

\section{EARLIER APPROACHES TO SELECTION}

The task of setting forth the criteria used to select materials for libraries offers an intriguing challenge and has appealed to many other writers. During the past few years, as the field of collection development has matured, a number of texts have appeared. As one would expect, certain themes are common to all attemptsquality of the materials, relationship to the patrons, cost-to name only the most frequent. Usually, however, treatments of selection decision making are very general, discursive, and incomplete. Moreover, the selection criteria are often tied to the scope and organization of specific tools.

An examination of major works by Arthur Curley and Dorothy Broderick, Robert Broadus, and William Katz shows that they all develop some general principles, concentrating, as textbooks must, on broad issues rather than on the intricacies of the decision-making process. When specific selection criteria are discussed, they are treated independently; that is, the authors do not relate the various criteria to each other. The reader is left wondering which criteria are the most important and when to apply them. Finally, all three texts focus on public libraries.

In Building Library Collections Curley and Broderick discuss some of the principles of selection using a series of nine debate topics. ${ }^{4}$ Under each one they present a range of contrasting viewpoints. The discussions are rarely prescriptive; indeed, they are not intended to be. Rather, they point to the diversity of opinion on such issues as high culture versus popular materials, catholicity in collecting, and demand as the governing factor in selection. Moreover, because the authors' primary intention is to stimulate thought, their principles do not serve as a guide to selection.

In his textbook, Selecting Materials for $\mathrm{Li}$ - braries, Broadus offers a wide-ranging exposition of the issues and practical wisdom about selecting books and most other types of library materials. ${ }^{5}$ Although not grouped conveniently, the principles he posits are (1) user needs as primary; (2) relation to existing collection; (3) relation to other libraries; (4) the sources or publishers; and (5) book-intrinsic criteria such as content, recency, veracity, reputation of the author or publisher, and format. While Broadus is a useful discussion of selection, the specific application of selection criteria is not developed.

In Collection Development: The Selection of Materials for Libraries, Katz advances a set of ten selection criteria. ${ }^{6}$ These are (1) purpose, scope, and audience; (2) difficulty; (3) authority, honesty, and credibility of author and publisher; (4) subject matter; (5) comparison of a title to others in the collection; (6) timeliness; (7) format; (8) price; (9) curriculum support; and (10) demand. We believe that these criteria touch upon most of the issues. However, as with the other survey texts, the relationship of the criteria to each other remains undeveloped.

Jean Boyer Hamlin, in a contributed chapter in Robert Stueart and George Miller's handbook on collection development, develops a list of nine selection criteria. ${ }^{7}$ Her factors, paraphrased, include (1) pertinence to areas covered, (2) interest to users, (3) relationship to existing collection, (4) cost, (5) patron objections and threat of theft, (6) probable quality, (7) necessity of continuing financial commitment, (8) duplication of existing material, and what might be called (9) "'bibliothecal convenience" or ease of handling. A more tightly organized grouping would simplify the classification, since some criteria are much more narrowly focused than others. In addition, the criteria are neither well developed nor prioritized. To illustrate practical decision making, Hamlin recasts the criteria into questions that should be asked when selecting books from a dealer's catalog. While these questions can help to refine one's thinking about a particular title, they provide no way of evaluating the results of the examination.

Recent journal literature has provided 
further attempts to delineate selection criteria, sometimes more focused on the decision-making process itself. Hendrik Edelman develops a model of decision making based on the organization of library materials by source and type of publication. ${ }^{8}$ He suggests that to this universe of published knowledge one may apply certain historical-, linguistic-, and geographical-elimination factors, correlated to the collection level descriptors. A further distinction is made between selection for short-term goals and selection for long-term goals. The main criteria, according to Edelman, are established by the collection development policy. To this policy one must bring to bear the virtues of "balance, reliability, and comprehensiveness, in that order. ${ }^{\prime \prime}$ This article is very general and does not discuss specific criteria, nor how they affect individual selection decisions. The suggestions, while accurate in the main, do not yield a guide to microdecision making; indeed, Edelman's main focus is macrodecision making.

In an article on selection decision making for preservation purposes, Dan C. Hazen develops another distinction. ${ }^{10}$ Pursuing the close relationship between preservation decisions and collection development decisions, Hazen adduces five criteria that pertain both to preservation and to new-title selection. These are (1) academic activity or user demand, (2) historical precedent and tradition, (3) the volume and cost of materials, (4) the availability of alternatives to purchase, and (5) discipline-specific models of access to information. These criteria apply best to preservation decisions; for acquisitions they are incomplete and lack specificity. Although most of these criteria are valid, no priority is assigned to them nor is a method of application suggested.

John N. DePew presents an explicit model of the acquisitions process, consisting of a detailed flow chart with weighted inputs and a formula that results in a selection decision. ${ }^{11}$ Although the article does make one aware of the complexity of selection, the criteria are inadequate and not well developed. In addition, they include considerations that should not be relevant, e.g., whether the requester will cause trouble or whether the title is a gift.
Finally, the formula he presents is very arbitrary and too cumbersome.

Ross Atkinson's recent article on what actually happens when collection development librarians select a title represents one of the few attempts to describe the selection process itself. ${ }^{12} \mathrm{His}$ article is useful for understanding some of the dynamics of selection microdecisions and how criteria relate to each other. Atkinson sees the selection process as the interaction of a selector with a bibliographic citation; the selector resolves the decision by using three contexts, the archival (what is already in the collection), the communal (the research needs and interests of the clientele), and the thematic (what has been or is being published on the subject). While this article is stimulating, it is primarily a theoretical treatment and not intended to be a practical guide to selecting. It is also too concentrated on the bibliographic citation itself to serve as a comprehensive guide to selection decision making.

Our review of the literature has not uncovered a practical and holistic model for microselection, the selection of materials on a title-by-title basis as is done in libraries every day. We see the need for the provision of a comprehensive and practical model that has a high level of applicability to any selection decision. The model presented in this article not only delineates and defines the appropriate criteria, but also displays them visually to show the relationship of the criteria to each other. In addition, we provide a numerical rating system to allow the librarian to rank each title and thereby relate selection to available funds.

\section{EVOLUTION OF THE MODEL}

The model consists of the criteria discussed below, coupled with a priority system, which grew out of the tasks and opportunities faced by collection development librarians at the University of North Carolina at Chapel Hill (UNC-CH). Collection development for the main library system at UNC-CH was totally reorganized during the mid-1970s, when selection became a library responsibility. At the same time the university and library administrations greatly increased funding for acquisitions. These two developments 
created expanded collection development possibilities, making selectors acutely aware of the selection process and the rationale for selection decision making. Since then, occasional budgetary reverses have given the selectors experience in the painful application of a triage system, in which all selections were classified as first, second, or third priority.

With the reorganization of collection development, long-standing cooperative acquisitions programs with neighboring research libraries took a new lease on life. ${ }^{13}$ This priority system has proven useful for cooperative collection development, particularly in facing the practical necessity of deciding which specific titles should be acquired locally and which should be acquired by the library holding the primary collection commitment. Within the context of broad cooperative agreements, a common understanding and an explicit statement of selection criteria encourage collection development librarians to think in terms of priorities and thereby to formulate cooperative programs with a large measure of specificity.

\section{REDEFINING THE SELECTION CRITERIA}

If, as Atkinson says, selection is difficult to describe, ${ }^{14}$ it is also difficult to prescribe. The selection criteria presented below are the results of years of wrestling with the intellectual issues involved in the selection of library materials. We have tried to include all the relevant factors involved in selection decision-making. For the sake of clarity we have arranged the factors into six internally coherent and, insofar as possible, mutually exclusive categories, thus avoiding redundancy. At the same time the arrangement indicates relationships between the criteria. Each of the criteria causes the selector to ask specific questions about any given title; in answering the questions the selector brings objective information to bear on making the decision.

\section{Subject}

Subject constitutes the first and most important selection factor. Since all books and other library materials are about something, both collection development policies and staff are typically organized along subject lines. The selector initially discerns the subject of a work, e.g., France-History-Revolution, or Science Fiction, then evaluates the item in terms of the information or knowledge universe. At the same time, and perhaps more importantly, he or she attempts to relate the item under consideration to the programs at his or her institution. How well the item supports institutional objectives and programs is the paramount consideration, but it is always seen in relation to the larger intellectual universe. Indeed, unless one knows the subject of a work, a rational selection decision cannot be made.

\section{Intellectual Content}

In actual practice, especially when selection decisions are made from a bibliographic citation, it is sometimes difficult to arrive at an informed estimate of the intellectual content of a work. Nevertheless, the question must be addressed. In assessing intellectual content, one asks how it relates to what has gone before. Is the work a key title in its field, whether a great work of literature or a seminal study? How valuable have the author's past contributions been? Is it "raw data" of the field such as statistical tables? How authoritative is the work and what is the nature of its contribution? Is it narrowly focused or a general essay? Or is the primary concern propagandistic? High intellectual content alone cannot determine the selection decision; nor can trivial or polemical works be rejected automatically, since they sometimes become the subject of research.

\section{Potential Use}

Having considered the work in terms of its subject relevance and its intrinsic intellectual integrity, the selector next reviews it in the light of his knowledge of the patrons' needs. Potential use is considered only after subject and intellectual content have been ascertained, in order to ensure that appropriate, quality materials are added. One must know what a work is about and something of the nature of its contents before one can predict level of use. What is the likelihood that the item in question will be used? What level of use justifies its acquisition? The selector 
should know of urgent research interests and be able to predict probable interest based on knowledge of the course offerings, research programs, and circulation patterns. There is also the category of broad, general information, material to which educated men and women will want to have recourse. These works are desirable but must take second place. At the lower end of the range are works that, because of considerations such as style or prerequisite knowledge, are deemed less accessible. From the bibliographic citation the selector can usually determine whether one use in fifty years would be the maximum expected.

\section{Relation to the Collection}

This factor echoes the concerns discussed under subject. Whereas subject relates an item to the information universe, here an item is scrutinized in terms of its relation to a specific library's collection. Typically the questions asked here are ones that will be posed by librarians, who, generally, are trained to look at the integrity of the library's collection, to fill in gaps in the collection, to establish balance and comprehensiveness in the collections, and to maintain cooperative programs with other libraries. Here there is an inherent tension: how to meet current user demands and yet continue to build upon historic collection strengths and specialties.

\section{Bibliographic Considerations}

To a certain extent you can judge a book by looking at its cover. Bibliographic considerations parallel those criteria found under intellectual content. The interrelated issues of publisher and format further refine the selection. The reputation of the publisher or sponsoring agency and the type of publication or format of the work both play an important role in any selection decision. Obviously these factors require some knowledge of the book trade. The highest priority within this category is assigned to the titles of distinguished publishing houses that over the years have built up a reputation for excellence. At the other extreme, there is a lush undergrowth of "quasi-publications" such as working papers and research reports. Between the two poles is a wide range of specialized publishing as well as the output of the major trade publishers, each of which has a reputation for quality and subject specialization.

\section{Language}

Language is a criterion because it speaks to the issue of potential use, yet it is distinct from it. Language also relates closely to the topic of the work. The major working language of a given field deserves special consideration. Similarily, the second working language of a topic will have to receive a relatively high priority. In some cases the major language of the topic will not be English. If the major language of a field is Italian, the selector cannot exclude an item in Italian if the topic is central. Does the language of the item augment or detract from the capacity of the work to inform? Travel guides in the vernacular, for example, may convey a fuller understanding of the country than English-language editions; on the other hand, a foreignlanguage book on computer science has little capacity to inform an Englishspeaking audience. Perhaps the foreignlanguage item helps to educate the potential user about areas not well covered in the English-language press? Or, would the language of the item have to be considered distant from its topic, e.g., Italianlanguage studies of Czech literature? Finally, hoping to gore as few oxen as possible, we recognize that some languages are less central to scholarly inquiry than others, although factors such as user interests can cause the item to receive an overall higher ranking than the language factor alone would indicate.

\section{Cost as a Nonfactor}

Although many writers include cost as a factor, price is irrelevant to making a selection decision as distinct from a purchase decision. We agree with Atkinson that "the budget should be viewed not as a criterion for selection but rather as an influence upon the relative extent to which selection criteria are acted upon." ${ }^{14}$ While high cost typically results in more care being taken in making the selection decision, the priorities-those items that the library must have, should have, or could havedo not change in response to budgetary 
limitations; they remain the same, whether money is available or not. Further, it should be noted that librarians generally select titles within specific budget lines, e.g., new subscriptions, audiovisuals, expensive titles, current books. As a consequence, a costly microform collection or multivolume set does not compete against a current book or a new journal subscription but against other possible expensive purchases. One can therefore use the proposed model to determine the relative priorities among a group of expensive titles. Finally, just as high cost should not influence a selection decision, low cost or bargain prices also should be irrelevant. If a title is ranked at priority three, its ranking does not change in response to the offer of a discount. Only when two items of equal ranking are being considered for acquisition in times of financial adversity might price determine which is actually purchased.

\section{USING THE MODEL}

In choosing a chart or tabular form of presentation, we are attempting to provide selectors with a succinct, rapidly scannable tool for guidance in title-by-title or microselection (see table 1). Although the model presented was developed in an academic library for the rationalization of book selection, it could be adapted with only slight modifications by any type of institution and can be applied to selection of all types of library material.

When deciding whether to acquire a title, a selector usually considers many factors of varying importance within the context of the inclusions and exclusions of a collection development policy. The factors that we consider most relevant are grouped into six columns. Each column contains a discrete set of criteria, made specific by descriptive phrases. The factors affecting selection are (1) subject, (2) intellectual content, (3) potential use, (4) relation to collection, (5) bibliographic considerations, and (6) language. Moreover, because some selection factors are more significant than others, the columnar sets are presented from left to right in descending order of importance. Although each column represents a distinct and internally coherent set of criteria, the second three columns echo respectively the first three. Using this model one evaluates each title horizontally in terms of the six selection factors and vertically in terms of its rank within each column.

Within each column the criteria are listed in descending order of importance. We have divided the columns to create three basic levels of priority: (1) the library must have the item: the title is essential and is the first to be reviewed against available funding; (2) the library should have the item: the title is an important addition to the collection, and users could reasonably expect to find it in the library; and (3) the library could acquire the title: although peripheral to the collection, the title is appropriate and there is a possibility that it will find a user.

There always will be a subjective element to selection and evaluation: it is an art-not an exact science. Nevertheless, there may be some circumstances in which one wishes to weigh each title quantitatively for the sake of comparison. In such instances we propose a method of assigning a relative value to each criterion considered in the evaluation (see table 2). One can thereby derive a numeric rating for each selection. It seems simplest to set up the selection values so that the highest possible score totals 100 points. The cumulative score is the total of the values assigned by the selector in each of the six columns.

The first factor, subject, carries the highest number of points: any item being evaluated receives a score of 1 to 30 points for subject. Intellectual content ranks just under subject with a slightly smaller range of 25 points possible; similarly, other factors receive proportionately fewer points. If a title receives 67 to 100 points, it ranks as a first priority; if a title receives 34 to 66 points, it scores as a second priority; and if 1 to 33 points, it equals a third priority.

The decision to assign a specific score of 16 points, rather than 25 , for subject within that allocated range will be determined by subjective judgments that cannot be eliminated from the selection process. Herein lies the art of selection. We also believe that some libraries will wish to change our weighting of the criteria. This can be simply done and would allow the 
TABLE 1

SELECTION CRITERIA

\begin{tabular}{|c|c|c|c|c|c|c|}
\hline & Subject & Intellectual Content & Potential Use & Relation to Collection & $\begin{array}{l}\text { Bibli } \\
\text { Consi }\end{array}$ & Language \\
\hline $\begin{array}{l}\text { First } \\
\text { Priority }\end{array}$ & $\begin{array}{l}\text { Directly supports } \\
\text { programs or } \\
\text { institutional } \\
\text { emphases } \\
\text { Major field of } \\
\text { scholarship or } \\
\text { inquiry }\end{array}$ & $\begin{array}{l}\text { Key work in field } \\
\text { Key author } \\
\text { Major critical study } \\
\text { Substantial new } \\
\text { contribution to } \\
\text { learning }\end{array}$ & $\begin{array}{l}\text { Known research or } \\
\text { program interest } \\
\text { Patron request, } \\
\text { based on need } \\
\text { Probable need, based } \\
\text { on known interest }\end{array}$ & $\begin{array}{l}\text { Central to existing } \\
\text { collection } \\
\text { Closely related } \\
\text { Provides specialized } \\
\text { information about a } \\
\text { central strength } \\
\text { Necessary to } \\
\text { intellectual integrity }\end{array}$ & $\begin{array}{l}\text { Distinguished } \\
\text { publisher } \\
\text { Significant } \\
\text { sponsoring body } \\
\text { Specialized publisher } \\
\text { of high quality } \\
\text { Major trade } \\
\text { publisher }\end{array}$ & $\begin{array}{l}\text { Major language(s) of } \\
\text { topic } \\
\text { English and second } \\
\text { working language(s) } \\
\text { of topic } \\
\text { Major foreign } \\
\text { language accessible } \\
\text { to users }\end{array}$ \\
\hline $\begin{array}{l}\text { Second } \\
\text { Priority }\end{array}$ & $\begin{array}{l}\text { Ancillary to } \\
\text { programs } \\
\text { Specialized topic } \\
\text { Minor field of } \\
\text { scholarship or } \\
\text { inquiry }\end{array}$ & $\begin{array}{l}\text { General essay } \\
\text { Narrowly focused } \\
\text { work } \\
\text { Narrow intellectual } \\
\text { perspective } \\
\text { Popular treatment }\end{array}$ & $\begin{array}{l}\text { General interest } \\
\text { Title recommended } \\
\text { by patron, without } \\
\text { specific need } \\
\text { Immediate use } \\
\text { unlikely }\end{array}$ & $\begin{array}{l}\text { Develops existing } \\
\text { collection strength } \\
\text { Historic collecting } \\
\text { strength }\end{array}$ & $\begin{array}{l}\text { Specialized publisher } \\
\text { Published } \\
\text { dissertation } \\
\text { Popular publisher }\end{array}$ & $\begin{array}{l}\text { Treatment in foreign } \\
\text { language of topic not } \\
\text { well covered in } \\
\text { English } \\
\text { Foreign language } \\
\text { treatment of } \\
\text { local/national issues }\end{array}$ \\
\hline $\begin{array}{l}\text { Third } \\
\text { Priority }\end{array}$ & $\begin{array}{l}\text { Tangential to } \\
\text { programs } \\
\text { Marginal area of } \\
\text { scholarship or } \\
\text { inquiry }\end{array}$ & $\begin{array}{l}\text { Raw or unedited } \\
\text { material } \\
\text { Marginal or } \\
\text { polemical work } \\
\text { Trivial literature } \\
\text { Propaganda }\end{array}$ & $\begin{array}{l}\text { Presents problems of } \\
\text { accessibility } \\
\text { Infrequent use }\end{array}$ & $\begin{array}{l}\text { Completes serial, } \\
\text { series, or set held } \\
\text { Very specialized } \\
\text { material } \\
\text { Assigned to } \\
\text { cooperative partner }\end{array}$ & $\begin{array}{l}\text { Research report } \\
\text { Unpublished } \\
\text { dissertation } \\
\text { Working papers } \\
\text { Pamphlets } \\
\text { Ephemera }\end{array}$ & $\begin{array}{l}\text { Foreign language } \\
\text { peripheral to topic or } \\
\text { user } \\
\text { Treatment in foreign } \\
\text { language of material } \\
\text { available in English } \\
\text { Language accessible } \\
\text { to tiny minority of } \\
\text { likely users }\end{array}$ \\
\hline
\end{tabular}


TABLE 2

SELECTION VALUES

\begin{tabular}{|c|c|c|c|c|c|c|}
\hline & $\begin{array}{c}\text { Subject } \\
\text { (30 points) }\end{array}$ & $\begin{array}{l}\text { Intellectual } \\
\text { Content } \\
\text { (25 points) }\end{array}$ & $\begin{array}{l}\text { Potential Use } \\
\text { (20 points) }\end{array}$ & $\begin{array}{l}\text { Relation to } \\
\text { Collection } \\
\text { (12 points) }\end{array}$ & $\begin{array}{l}\text { Bibliographic } \\
\text { Considerations } \\
\text { (8 points) }\end{array}$ & $\begin{array}{l}\text { Language } \\
\text { (5 points) }\end{array}$ \\
\hline $\begin{array}{l}\text { First } \\
\text { Priority }\end{array}$ & $\begin{array}{l}30 \\
29 \\
28 \\
27 \\
26 \\
25 \\
24 \\
23 \\
22 \\
21\end{array}$ & $\begin{array}{r}25 \\
24 \\
23 \\
22 \\
21 \\
20 \\
19 \\
18 \\
17 \\
0\end{array}$ & $\begin{array}{r}20 \\
19 \\
18 \\
17 \\
16 \\
15 \\
14 \\
0 \\
0 \\
0\end{array}$ & $\begin{array}{r}12 \\
11 \\
10 \\
9 \\
0 \\
0 \\
0 \\
0 \\
0 \\
0\end{array}$ & $\begin{array}{l}8 \\
7 \\
6 \\
0 \\
0 \\
0 \\
0 \\
0 \\
0 \\
0\end{array}$ & $\begin{array}{l}5 \\
4 \\
0 \\
0 \\
0 \\
0 \\
0 \\
0 \\
0 \\
0\end{array}$ \\
\hline $\begin{array}{l}\text { Second } \\
\text { Priority }\end{array}$ & $\begin{array}{l}20 \\
19 \\
18 \\
17 \\
16 \\
15 \\
14 \\
13 \\
12 \\
11\end{array}$ & $\begin{array}{r}16 \\
15 \\
14 \\
13 \\
12 \\
11 \\
10 \\
9 \\
0 \\
0\end{array}$ & $\begin{array}{r}13 \\
12 \\
11 \\
10 \\
9 \\
8 \\
7 \\
0 \\
0 \\
0\end{array}$ & $\begin{array}{l}8 \\
7 \\
6 \\
5 \\
0 \\
0 \\
0 \\
0 \\
0 \\
0\end{array}$ & $\begin{array}{l}5 \\
4 \\
3 \\
0 \\
0 \\
0 \\
0 \\
0 \\
0 \\
0\end{array}$ & $\begin{array}{l}3 \\
2 \\
0 \\
0 \\
0 \\
0 \\
0 \\
0 \\
0 \\
0\end{array}$ \\
\hline $\begin{array}{l}\text { Third } \\
\text { Priority }\end{array}$ & $\begin{array}{r}10 \\
9 \\
8 \\
7 \\
6 \\
5 \\
4 \\
3 \\
2 \\
1\end{array}$ & $\begin{array}{l}8 \\
7 \\
6 \\
5 \\
4 \\
3 \\
2 \\
1 \\
0 \\
0\end{array}$ & $\begin{array}{l}6 \\
5 \\
4 \\
3 \\
2 \\
1 \\
0 \\
0 \\
0 \\
0\end{array}$ & $\begin{array}{l}4 \\
3 \\
2 \\
1 \\
0 \\
0 \\
0 \\
0 \\
0 \\
0\end{array}$ & $\begin{array}{l}2 \\
1 \\
0 \\
0 \\
0 \\
0 \\
0 \\
0 \\
0 \\
0\end{array}$ & $\begin{array}{l}1 \\
0 \\
0 \\
0 \\
0 \\
0 \\
0 \\
0 \\
0 \\
0\end{array}$ \\
\hline
\end{tabular}

results to reflect local emphases more closely. In any case, such a point system could then be correlated with available funding to determine which selections are actually purchased.

By no means do we wish to suggest that every title needs to be treated with such mathematical precision. A library could limit its use to certain classes of materials that require particular selection care (e.g., reference titles); special formats (e.g., audiovisuals); expensive items (e.g., books costing more than $\$ 100$ ); or critical budget lines (e.g., new subscriptions). Furthermore, since the first three criteria are more heavily weighted to reflect their greater importance, it will not always be necessary to go through the entire grid in order to arrive at a title's relative priority, particularly since the second three factors echo the first three and carry far less weight.

\section{IMPLICATIONS OF THE MODEL}

The proposed model will find its greatest utility in adding precision to and enhancing the consistency of the individual selection decisions. Consequently, use of this model can improve the quality of a library's collection development efforts. Moreover, because the schema presented here is comprehensive, holistic, and explicit, it can serve as a practical guide for training all selectors in a library and can aid in the rationalization of selection decision making throughout a library system. If all selectors have a similar understand-. ing of the criteria to be used and their interrelatedness, then unintended disparities in collecting levels can be minimized.

By extension, the model has applicability to cooperative collection development programs. In our experience we have 
found that cooperation with other libraries is most practicable when lower priority materials are under discussion. Because no library is likely to forego the purchases of first priority items, it is in the realm of less essential titles that cooperation is most likely to work. The model we have presented here can help to make sure that selectors at all participating libraries understand what kinds of materials can be acquired cooperatively.

This model also allows a library to relate selection decisions to a library's fiscal environment both generally and specifically. The model operates generally through the assignment of a first, second, or third priority, and specifically through the development-when necessary - of a precise numeric rating. This rating could then be correlated with a certain level of funding.
Finally, our schema can have a great public relations value both within the library and without. Since many departments within the library often do not fully understand the work done by collection development, this model can be used to explain to other librarians and staff how selection decisions are reached. Indeed, with the chart one can stress the rational quality of the decisions and demonstrate to colleagues that materials are being carefully chosen. The chart is also useful for educating faculty, some of whom may lack confidence in selection done by librarians. Moreover, by modeling selection in explicit and rational terms, a library can demonstrate to its parent institution as well as to outside agencies-who often view acquisitions as a bottomless pit-that the "misery" of making choices is governed by reasonable processes.

\section{REFERENCES AND NOTES}

1. See, for example, General Library, University of California, Berkeley, Collection Development Policy Statement (Berkeley, Calif.: General Library, 1980); Collection Development Office, Stanford University Libraries, The Libraries of Stanford University Collection Development Policy Statement, (Stanford, Calif.: Office, 1980); General Libraries, University of Texas at Austin, Collection Development Policy, 2d ed. (Austin, Tex.: General Libraries, 1980); and Harold B. Lee Library, Brigham Young University, Collection Development Policy Statement (Provo, Utah: Library, 1985).

2. General Libraries, University of Texas at Austin, Bibliographer's Manual: A Guide to the General Libraries Collection Development Program (Austin, Tex.: General Libraries, 1982).

3. Collection Development Committee, Resources and Technical Services Division, American Library Association, Guidelines for Collection Development (Chicago: American Library Assn., 1979).

4. Arthur Curley and Dorothy Broderick, Building Library Collections, 6th ed. (Metuchen, N.J.: Scarecrow, 1985).

5. Robert N. Broadus, Selecting Materials for Libraries, 2d ed. (New York: Wilson, 1981).

6. William A. Katz, Collection Development: The Selection of Materials for Libraries, (New York: Holt, 1980).

7. Jean Boyer Hamlin, "The Selection Process," in Collection Development in Libraries: A Treatise, Robert E. Stueart and George B. Miller, Jr., ed. (Greenwich, Conn.: JAI Pr., 1980), p.185-201.

8. Hendrik Edelman, "Selection Methodologies in Academic Libraries," Library Resources \& Technical Services 23:33-38 (Winter 1979).

9. Ibid., p.36.

10. Dan C. Hazen, "Collection Development, Collection Management, and Preservation," Library Resources \& Technical Services 26:3-11 (Jan.-Mar. 1982).

11. John N. DePew, "An Acquisitions Decision Model for Academic Libraries," Journal of the American Society for Information Science 26:230-46 (1975).

12. Ross Atkinson, "The Citation as Intertext: Toward a Theory of the Selection Process," Library Resources \& Technical Services 28:109-19 (Apr.-June 1984).

13. For an overview, see Joe A. Hewitt, "Cooperative Collection Development Programs of the Triangle Research Libraries Network," Resource Sharing and Information Networks 2:139-50 (Spring-Summer 1985).

14. Atkinson, "The Citation as Intertext," p.209.

15. Ibid., p. 229. 